\title{
Effect of Deficit Irrigation and Plastic Mulch on Yield and Water Use Efficiency of Drip Irrigated Capsicum under Naturally Ventilated Polyhouse
}

\author{
Dimple $^{1 *}$, S.R. Bhakar ${ }^{2}$, S.S. Lakhawat ${ }^{3}$ and M. Kothari ${ }^{2}$ \\ ${ }^{1}$ College of Technology and Engineering, MPUAT, Udaipur-313001, India \\ ${ }^{2}$ Department of Soil and Water Engineering, College of Technology and Engineering, \\ MPUAT, Udaipur, India \\ ${ }^{3}$ Department of Horticulture, Rajasthan College of Agriculture, MPUAT, Udaipur, India \\ *Corresponding author
}

\begin{tabular}{|c|c|}
\hline & A B S T R A C T \\
\hline $\begin{array}{l}\text { K e y w o r d s } \\
\text { Deficiti irrigation, Drip } \\
\text { irrigation, Naturally } \\
\text { ventilated polyhouse, } \\
\text { Plastic mulch, Water use } \\
\text { efficiency and capsicum } \\
\text { crop. }\end{array}$ & \multirow{3}{*}{$\begin{array}{l}\text { The effect of deficit irrigation on yield and water use efficiency of drip irrigated capsicum } \\
\text { under the naturally ventilated polyhouse was studied through field experiment. In this } \\
\text { study, six different levels of drip irrigation equivalent to } 100 \%, 90 \%, 80 \%, 70 \%, 60 \% \text { and } \\
100 \% \text { (control without mulch) of crop evapotranspiration with four replications were } \\
\text { considered for their effect on crop yield and water use efficiency inside the naturally } \\
\text { ventilated polyhouse. Capsicum (Capsicum annuum L. Indra Variety) plants were grown } \\
\text { under the naturally ventilated polyhouse. The maximum crop yield was found in case of } 80 \\
\% \text { irrigation level ( } 42.64 \mathrm{t} / \mathrm{ha} \text { ) and the maximum water use efficiency was also recorded in } \\
\text { the same treatment ( } 1296.48 \mathrm{~kg} / \mathrm{ha}-\mathrm{cm} \text { ). Thus, the results revealed that all the vegetative } \\
\text { parameters, quantity parameter and water use efficiency were found maximum at drip } \\
\text { irrigation level equal to } 80 \% \text { of crop evapotranspiration under the naturally ventilated } \\
\text { polyhouse. }\end{array}$} \\
\hline Article Info & \\
\hline $\begin{array}{l}\text { Accepted: } \\
\text { 21 October } 2017 \\
\text { Available Online: } \\
\text { 10 December } 2017\end{array}$ & \\
\hline
\end{tabular}

\section{Introduction}

Polyhouse cultivation gives higher yield, higher productivity, better quality produce and production throughout the year (Neelam and Rajput, 2010). Capsicum, also known as sweet pepper, bell pepper or Shimla Mirch is one of the popular vegetables grown throughout India. It is rich in Vitamin A (8493 IU), Vitamin C (283 mg) and minerals like Calcium (13.4 mg), Magnesium (14.9 mg) Phosphorus (28.3 mg) Potassium, (263.7 $\mathrm{mg}$ ) per $100 \mathrm{~g}$ fresh weight. Capsicum is a cool season crop, but it can be grown round the year using protected structures where temperature and relative humidity $(\mathrm{RH})$ can be manipulated. This crop requires day temperature of $25-30^{\circ} \mathrm{C}$ and night temperature of $18-20^{\circ} \mathrm{C}$ with relative humidity of $50-60$ $\%$. If temperature exceeds $35^{\circ} \mathrm{C}$ or falls below $12^{\circ} \mathrm{C}$, fruit setting is affected (Shankara et al., 2011).

India is the second largest producer of vegetables in the world and the concerted efforts of vegetable research and emergence of corporate sector in vegetable seeds have contributed immensely in enhancing productivity and production of vegetables in our country but still there exists a gap of $10.1 \%$ in national productivity in comparison to global scenario. Further, $62.1 \%$ (18 out of 
29 states) states in the country are having lower productivity in comparison to national productivity of vegetable $17.8 \mathrm{t} / \mathrm{ha}$ (Anonymous, 2016). Mulch is a covering placed over the soil around the plants. Plastic mulch on the surface of the soil causes change in the microclimate on its vicinity.

This results in moisture conservation, less soil compaction and higher $\mathrm{CO}_{2}$ levels around plants (Mane and Umrani, 1981). Mulching is an effective method of manipulating the cropgrowing environment to increase crop yield and improve product quality by controlling soil temperature, retaining soil moisture and reducing soil evaporation (Chakraborty et al., 2008).

Sharma et al., (1990) found that application of maize stalk mulching increased residual soil moisture in sandy loam soil. Olasantan (1999) and Fabrizzi et al., (2005) reported that soil temperature was increased during colder weather and decreased during warmer weather in mulched condition compared to in non-mulched condition. Some other benefits of mulching such as weed control, reduction of soil runoff and erosion, and improvement of plant earliness have also been recognized widely by both researchers and farmers (Dong et al., 2009; Jordan et al., 2010).

The drip irrigation adoption increases of water use efficiency (60-200\%), saves water (20-60\%), reduces fertilization requirement (20-30\%) through fertigation, produces better quality crop and increases yield (7-25\%) as compared with conventional irrigation (Kaushal et al., 2012). Drip is an irrigation technology known to increase the control of water application and offers several advantages to growers. It reduces soil evaporation and weed population, increases plant transpiration, and when well-managed, excessive water drainage is unlikely to occur, thus allowing nutrients to be retained in the root zone for prolonged periods. Moreover, drip offers an opportunity to inject soluble fertilizers combined with irrigation, a process known as fertigation (Cabrera et al., 2016).

The drip irrigation adoption increases of water use efficiency (60-200\%), saves water (20-60\%), reduces fertilization requirement (20-30\%) through fertigation, produces better quality crop and increases yield (7-25\%) as compared with conventional irrigation (Kaushal et al., 2012). Capsicum yields in open field cultivation ranges between 20-40 $\mathrm{t} / \mathrm{ha}$, where as in a greenhouse the yield range is from 100-120 t/ha (Thangam et al., 2013).

Water productivity $\left(\mathrm{kg} / \mathrm{m}^{3}\right)$ is defined as crop yield (kg) per accumulated actual evapotranspiration for the growing season $\left(\mathrm{m}^{3}\right)$ (World Bank, 2003). Thereby, the objectives of current research was to assess the effect of deficit irrigation and plastic mulch on yield and water use efficiency of capsicum crop under naturally ventilated polyhouse.

\section{Materials and Methods}

A naturally ventilated polyhouse was constructed at the Plasticulture farm of College of Technology and Engineering, MPUAT Udaipur (at the elevation $582.17 \mathrm{~m}$ above mean sea level, $24^{\circ} 35^{\prime} 31.5^{\prime \prime}$ to $24^{\circ}$ $35^{\prime} 38.5^{\prime \prime}$ N-latitude, $73^{\circ} 44^{\prime} 18.2^{\prime \prime}$ to $73^{\circ}$ 44'21.1" E-longitude). The Udaipur comes under dry, sub-humid agro-climatic region. It receives an average annual rainfall of 654.3 $\mathrm{mm}$, most of the received during the period of July to September. The maximum temperature goes as high as $46{ }^{\circ} \mathrm{C}$ during summer and minimum as below as $5{ }^{\circ} \mathrm{C}$ during winter months. The atmospheric humidity is high from June to October. The experiment was conducted during the period of March, 2017 to August, 2017 in randomized block design with four 
replications under the naturally ventilated polyhouse. Thereafter, six treatments were also being randomly arranged in the equally sized beds of $8 \mathrm{~m} \times 1 \mathrm{~m}$ area. The total are of the experimental field size was $192 \mathrm{~m}^{2}$. The deficit irrigation treatments were given below:

$\mathrm{T}_{1}$ : Drip irrigation with $100 \%$ of $\mathrm{ET}_{\mathrm{c}}$ with mulch

$\mathrm{T}_{2}$ : Drip irrigation with $90 \%$ of $\mathrm{ET}_{\mathrm{c}}$ with mulch

$\mathrm{T}_{3}$ : Drip irrigation with $80 \%$ of $\mathrm{ET}_{\mathrm{c}}$ with mulch

$\mathrm{T}_{4}$ : Drip irrigation with $70 \%$ of $\mathrm{ET}_{\mathrm{c}}$ with mulch

$\mathrm{T}_{5}$ : Drip irrigation with $60 \%$ of $\mathrm{ET}_{\mathrm{c}}$ with mulch

$\mathrm{T}_{6}$ : Drip irrigation with $100 \%$ of $\mathrm{ET}_{\mathrm{C}}$ without mulch (Control)

The observations were recorded on biometric observations like plant height $(30,60,90$, 120,150 DAT), no. of leaves per plant $(30,60$, 90, 120,150 DAT), time required for first harvest, reproductive parameters like number of flowers per plant (60, 90, 120,150 DAT), number of fruits per plant $(60,90,120,150$ DAT), time taken for flower initiation, per cent fruit set, and quality parameters like individual fruit weight $(\mathrm{g})$, fruit yield per tagged plant, etc. and water use efficiency.

\section{Per cent fruit set}

Ten unopened buds were tagged at random in each of the plant under observation. The number of fruit set from the tagged buds was recorded periodically and per cent fruit set was estimated by formula
Percent fruit set $(\%)=\frac{\text { Number of fruits set }}{\text { Number of flowers tagged }} \times 100$

Crop water use efficiency is the ratio of crop yield to the amount of water depleted by the crop in the process of evaporation.

WUE $=\frac{\mathrm{Y}}{\mathrm{WR}}$

Where,

WUE $=$ Water use efficiency, $\left(\mathrm{kg} / \mathrm{m}^{3}\right)$

$\mathrm{Y}=$ Crop yield, $\left(\mathrm{kg} / \mathrm{m}^{2}\right)$

$\mathrm{WR}=\mathrm{Water}$ requirement, $(\mathrm{m})$

\section{Results and Discussion}

All the biometric and reproductive parameters differed significantly due to different irrigation treatments. The plant height, number of leaves, time required for first harvest were maximum under $\mathrm{T}_{3}$ at all stages of crop growth viz., 30, 60, 90, 120 and 150 DAT. The number of flowers and fruits per plant was higher under $\mathrm{T}_{3}$ at all stages of crop growth viz., 60, 90, 120 and 150 DAT (days after transplanting).

The maximum (180 $\mathrm{cm}$ and 57.28) plant height and no. of leaves presented and represented in Table 1, 2 and Figure 1 and 2, maximum (17.78 and 11.31) number of flowers and fruits were recorded under $T_{3}$ at 150 DAT presented and represented in Table 4, 5 and Figure 4 and 5, respectively. Similar findings were recorded by Arya et al., (2017).

The maximum time taken for flower initiation (26.00) and that for first harvest (60.00) were recorded under $T_{3}$ presented and represented in Table 3 and Figure 3. The maximum $(51.07 \%)$ fruit set was recorded under $\mathrm{T}_{3}$ presented and represented in Table 5 and Figure 6. individual fruit weight (94.33 g), fruit yield per plant (1065.98 gm), fruit yield 
per sqm area (4263.93 gm), fruit yield (42.64 ton/ha) and water use efficiency (1296.48 $\mathrm{kg} / \mathrm{ha}-\mathrm{cm}$ ) shown in Table 6 and 7 and Figure
7, 8, 9, 10 and 11. Among the different irrigation treatments maximum values were recorded in $\mathrm{T}_{3}$ for all observations.

Table.1 Effect of deficit irrigation on plant height of capsicum crop

\begin{tabular}{|c|c|c|c|c|c|}
\hline \multirow{2}{*}{ Treatments } & \multicolumn{5}{|c|}{ Mean plant height, (cm) } \\
\cline { 2 - 6 } & 30 DAT & 60 DAT & 90 DAT & 120 DAT & 150 DAT \\
\hline $\mathbf{T}_{\mathbf{1}}$ & 68.55 & 92.55 & 104.95 & 121.40 & 169.90 \\
\hline $\mathbf{T}_{\mathbf{2}}$ & 70.65 & 95.15 & 108.35 & 134.90 & 174.90 \\
\hline $\mathbf{T}_{\mathbf{3}}$ & 73.25 & 97.75 & 115.00 & 152.80 & 180.00 \\
\hline $\mathbf{T}_{\mathbf{4}}$ & 68.20 & 90.85 & 101.50 & 117.00 & 167.75 \\
\hline $\mathbf{T}_{\mathbf{5}}$ & 65.00 & 86.10 & 96.50 & 100.00 & 157.00 \\
\hline $\mathbf{T}_{\mathbf{6}}$ & 66.20 & 89.35 & 98.80 & 112.45 & 164.05 \\
\hline $\mathbf{S E}_{\mathbf{m}} \pm$ & $\mathbf{1 . 0 4}$ & $\mathbf{1 . 5 8}$ & $\mathbf{1 . 4 5}$ & $\mathbf{2 . 4 1}$ & $\mathbf{2 . 1 4}$ \\
\hline $\mathbf{C D}(\mathbf{p}=\mathbf{0 . 0 5})$ & $\mathbf{3 . 1 3}$ & $\mathbf{4 . 7 7}$ & $\mathbf{4 . 3 8}$ & $\mathbf{7 . 2 8}$ & $\mathbf{6 . 4 5}$ \\
\hline
\end{tabular}

Table.2 Effect of deficit irrigation on number of leaves of capsicum crop

\begin{tabular}{|c|c|c|c|c|c|}
\hline \multirow{2}{*}{ Treatments } & \multicolumn{5}{|c|}{ Mean number of leaves per plant } \\
\cline { 2 - 6 } & 30 DAT & 60 DAT & 90 DAT & 120 DAT & 150 DAT \\
\hline $\mathbf{T}_{\mathbf{1}}$ & 16.15 & 22.43 & 31.87 & 41.24 & 51.54 \\
\hline $\mathbf{T}_{\mathbf{2}}$ & 17.10 & 24.89 & 33.49 & 42.81 & 54.38 \\
\hline $\mathbf{T}_{\mathbf{3}}$ & 19.70 & 28.00 & 36.34 & 47.13 & 57.28 \\
\hline $\mathbf{T}_{\mathbf{4}}$ & 16.10 & 22.10 & 28.25 & 35.53 & 45.06 \\
\hline $\mathbf{T}_{\mathbf{5}}$ & 15.90 & 20.00 & 25.00 & 31.26 & 40.56 \\
\hline $\mathbf{T}_{\mathbf{6}}$ & 15.65 & 21.23 & 26.80 & 33.24 & 41.05 \\
\hline $\mathbf{S E}_{\mathbf{m}} \mathbf{}$ & $\mathbf{0 . 6 3}$ & $\mathbf{0 . 7 9}$ & $\mathbf{0 . 4 9}$ & $\mathbf{0 . 4 3}$ & $\mathbf{0 . 5 0}$ \\
\hline $\mathbf{C D}(\mathbf{p}=\mathbf{0 . 0 5})$ & $\mathbf{1 . 8 9}$ & $\mathbf{2 . 3 9}$ & $\mathbf{1 . 4 9}$ & $\mathbf{1 . 2 9}$ & $\mathbf{1 . 5 1}$ \\
\hline
\end{tabular}

Table.3 Effect of deficit irrigation on time taken for flower initiation and on first harvest of capsicum crop

\begin{tabular}{|c|c|c|}
\hline Treatments & Number of days to flowering & Number of days to harvest \\
\hline $\mathbf{T}_{\mathbf{1}}$ & 28.00 & 64.75 \\
\hline $\mathbf{T}_{\mathbf{2}}$ & 27.25 & 62.75 \\
\hline $\mathbf{T}_{\mathbf{3}}$ & 26.00 & 60.00 \\
\hline $\mathbf{T}_{\mathbf{4}}$ & 28.75 & 67.75 \\
\hline $\mathbf{T}_{\mathbf{5}}$ & 31.50 & 71.50 \\
\hline $\mathbf{T}_{\mathbf{6}}$ & 30.00 & 69.25 \\
\hline $\mathbf{S E m} \pm$ & $\mathbf{1 . 0 5}$ & $\mathbf{1 . 7 4}$ \\
\hline $\mathbf{C D}(\mathbf{p}=\mathbf{0 . 0 5})$ & $\mathbf{3 . 1 7}$ & $\mathbf{5 . 2 5}$ \\
\hline
\end{tabular}


Table.4 Effect of deficit irrigation on number of flowers per plant of capsicum crop

\begin{tabular}{|c|c|c|c|c|}
\hline \multirow{2}{*}{ Treatments } & \multicolumn{4}{|c|}{ Mean number of flower per plant } \\
\cline { 2 - 5 } & $\mathbf{6 0}$ DAT & 90 DAT & 120 DAT & 150 DAT \\
\hline $\mathbf{T}_{\mathbf{1}}$ & 6.77 & 9.88 & 12.08 & 15.28 \\
\hline $\mathbf{T}_{\mathbf{2}}$ & 8.23 & 10.48 & 12.58 & 16.08 \\
\hline $\mathbf{T}_{\mathbf{3}}$ & 9.21 & 11.98 & 15.18 & 17.78 \\
\hline $\mathbf{T}_{\mathbf{4}}$ & 6.45 & 9.48 & 11.68 & 14.48 \\
\hline $\mathbf{T}_{\mathbf{5}}$ & 6.00 & 8.68 & 10.78 & 12.98 \\
\hline $\mathbf{T}_{\mathbf{6}}$ & 6.35 & 9.08 & 11.28 & 13.88 \\
\hline $\mathbf{S E m} \pm$ & $\mathbf{0 . 0 9}$ & $\mathbf{0 . 0 7}$ & $\mathbf{0 . 1 8}$ & $\mathbf{0 . 1 5}$ \\
\hline $\mathbf{C D}(\mathbf{p}=\mathbf{0 . 0 5})$ & $\mathbf{0 . 2 7}$ & $\mathbf{0 . 2 2}$ & $\mathbf{0 . 5 5}$ & $\mathbf{0 . 4 5}$ \\
\hline
\end{tabular}

Table.5 Effect of deficit irrigation on number of fruits per plant and percent fruit set of capsicum crop

\begin{tabular}{|c|c|c|}
\hline Treatments & Number of fruits per plant & Percent fruit set $(\%)$ \\
\hline $\mathbf{T}_{\mathbf{1}}$ & 8.76 & 43.82 \\
\hline $\mathbf{T}_{\mathbf{2}}$ & 9.36 & 47.16 \\
\hline $\mathbf{T}_{\mathbf{3}}$ & 11.31 & 51.07 \\
\hline $\mathbf{T}_{\mathbf{4}}$ & 8.23 & 40.34 \\
\hline $\mathbf{T}_{\mathbf{5}}$ & 7.03 & 32.17 \\
\hline $\mathbf{T}_{\mathbf{6}}$ & 7.63 & 36.91 \\
\hline $\mathbf{S E m} \pm$ & $\mathbf{0 . 2 1}$ & $\mathbf{0 . 8 0}$ \\
\hline $\mathbf{C D}(\mathbf{p}=\mathbf{0 . 0 5})$ & $\mathbf{0 . 6 3}$ & $\mathbf{2 . 4 2}$ \\
\hline
\end{tabular}

Table.6 Effect of deficit irrigation on quantity parameters of capsicum crop

\begin{tabular}{|c|c|c|c|c|}
\hline Treatments & $\begin{array}{c}\text { Individual fruit } \\
\text { weight }(\mathbf{g m})\end{array}$ & $\begin{array}{c}\text { Fruit yield/plant } \\
\mathbf{( g m})\end{array}$ & $\begin{array}{c}\text { Fruit yield/sqm } \\
\text { area }(\mathbf{g m})\end{array}$ & $\begin{array}{c}\text { Fruit yield } \\
\text { (ton/ha) }\end{array}$ \\
\hline $\mathbf{T}_{\mathbf{1}}$ & 74.33 & 651.14 & 2604.57 & 26.05 \\
\hline $\mathbf{T}_{\mathbf{2}}$ & 83.43 & 780.99 & 3123.94 & 31.24 \\
\hline $\mathbf{T}_{\mathbf{3}}$ & 94.33 & 1065.98 & 4263.93 & 42.64 \\
\hline $\mathbf{T}_{\mathbf{4}}$ & 67.12 & 552.40 & 2209.61 & 22.10 \\
\hline $\mathbf{T}_{\mathbf{5}}$ & 42.53 & 298.98 & 1195.91 & 11.96 \\
\hline $\mathbf{T}_{\mathbf{6}}$ & 56.34 & 429.87 & 1719.47 & 17.19 \\
\hline $\mathbf{S E m} \pm$ & $\mathbf{4 . 4 4}$ & $\mathbf{4 3 . 2 8}$ & $\mathbf{1 7 3 . 1 3}$ & $\mathbf{1 . 7 3}$ \\
\hline $\mathbf{C D}(\mathbf{p}=\mathbf{0 . 0 5})$ & $\mathbf{1 3 . 3 8}$ & $\mathbf{1 3 0 . 4 7}$ & $\mathbf{5 2 1 . 8 7}$ & $\mathbf{5 . 2 2}$ \\
\hline
\end{tabular}

Table.7 Effect of different treatments on water use efficiency

\begin{tabular}{|c|c|}
\hline Treatments & Water use efficiency kg/ha-cm \\
\hline $\mathbf{T}_{\mathbf{1}}$ & 633.55 \\
\hline $\mathbf{T}_{\mathbf{2}}$ & 844.32 \\
\hline $\mathbf{T}_{\mathbf{3}}$ & 1296.48 \\
\hline $\mathbf{T}_{\mathbf{4}}$ & 767.83 \\
\hline $\mathbf{T}_{\mathbf{5}}$ & 484.84 \\
\hline $\mathbf{T}_{\mathbf{6}}$ & 327.45 \\
\hline
\end{tabular}


Fig.1 Effect of deficit irrigation on plant height

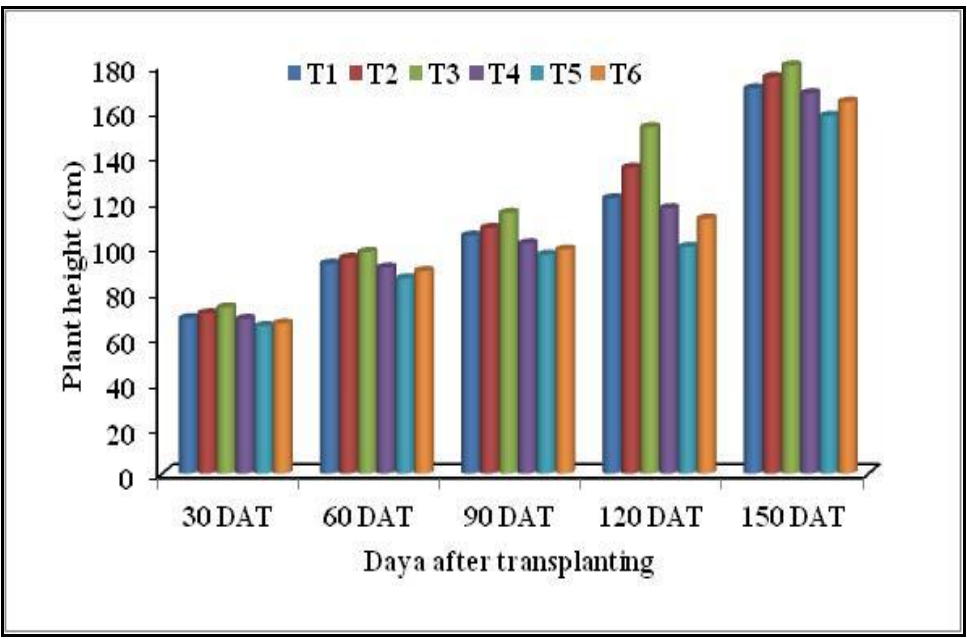

Fig.2 Effect of deficit irrigation on number of leaves

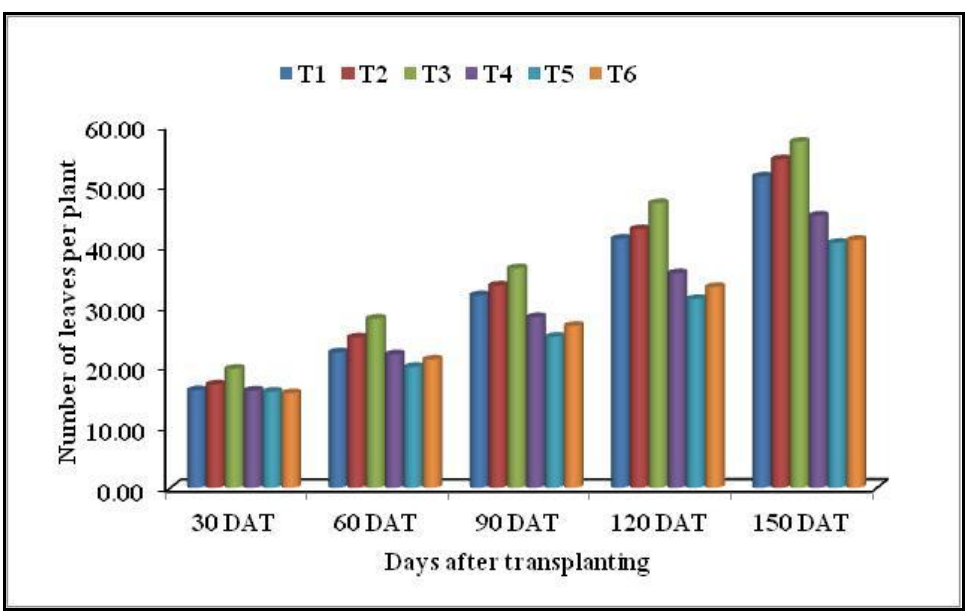

Fig.3 Effect of deficit irrigation on time taken for flower initiation and on first harvest

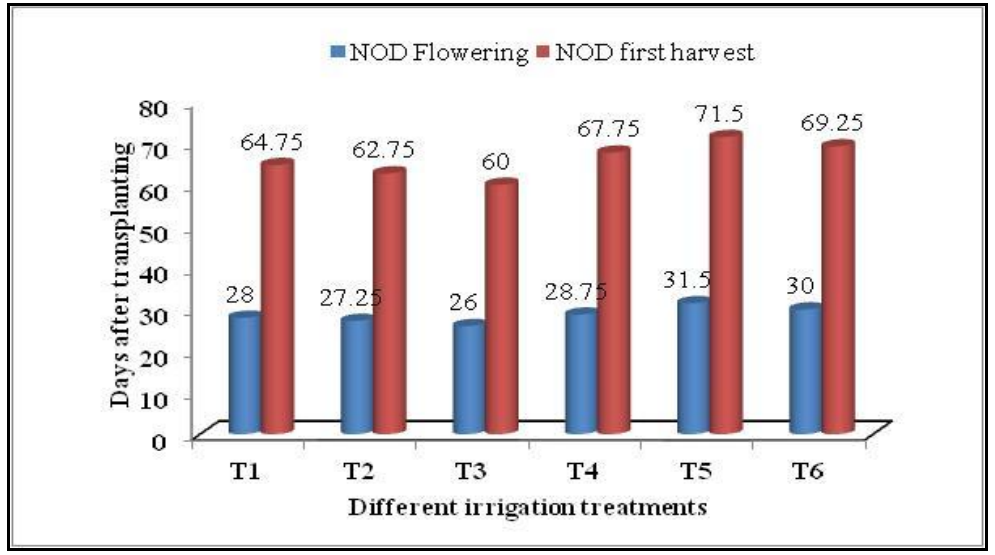


Fig.4 Effect of deficit irrigation on number of flowers per plant

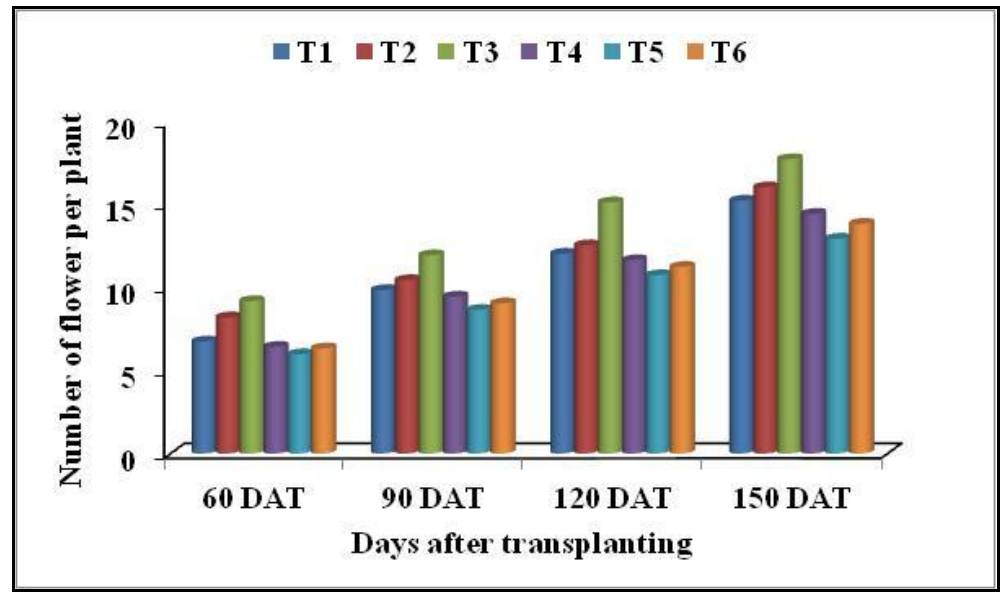

Fig.5 Effect of deficit irrigation on number of fruits per plant

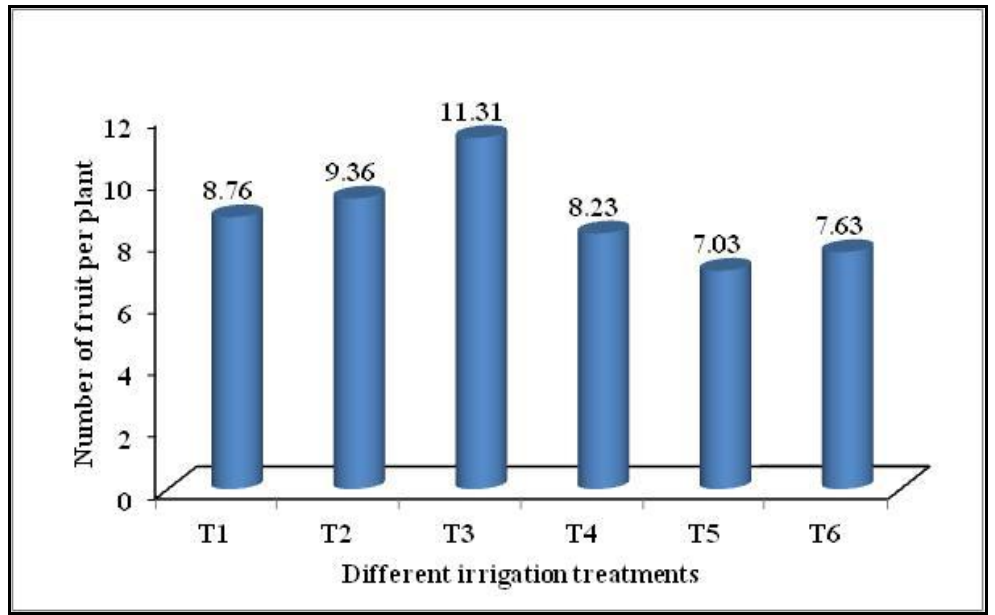

Fig.6 Effect of deficit irrigation on percent fruit set

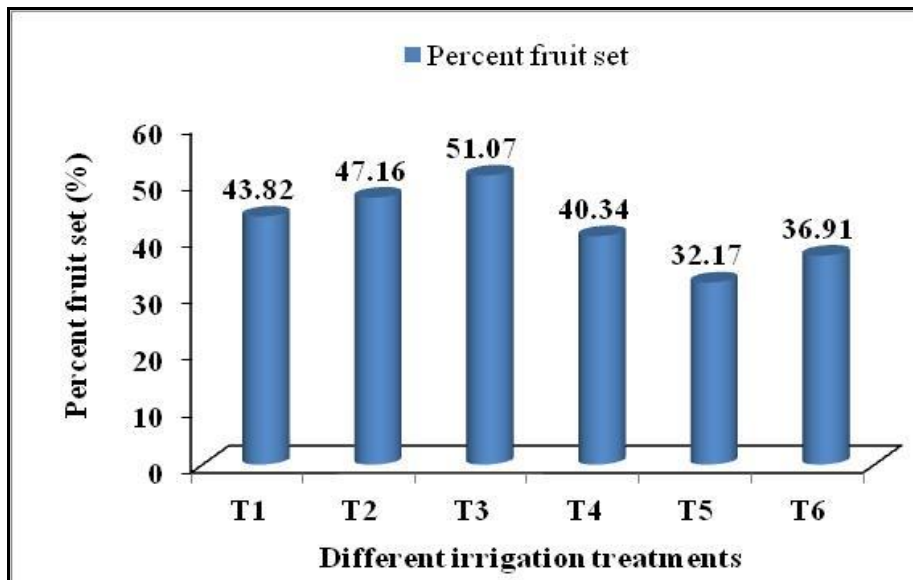


Fig.7 Effect of deficit irrigation on individual fruit weight

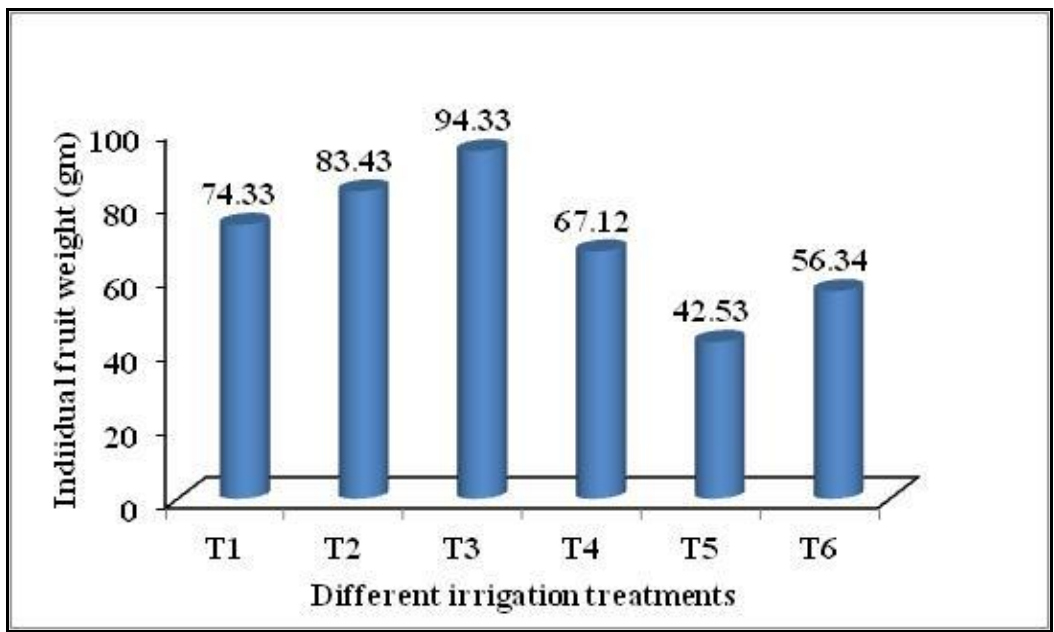

Fig.8 Effect of deficit irrigation on fruit yield per plant

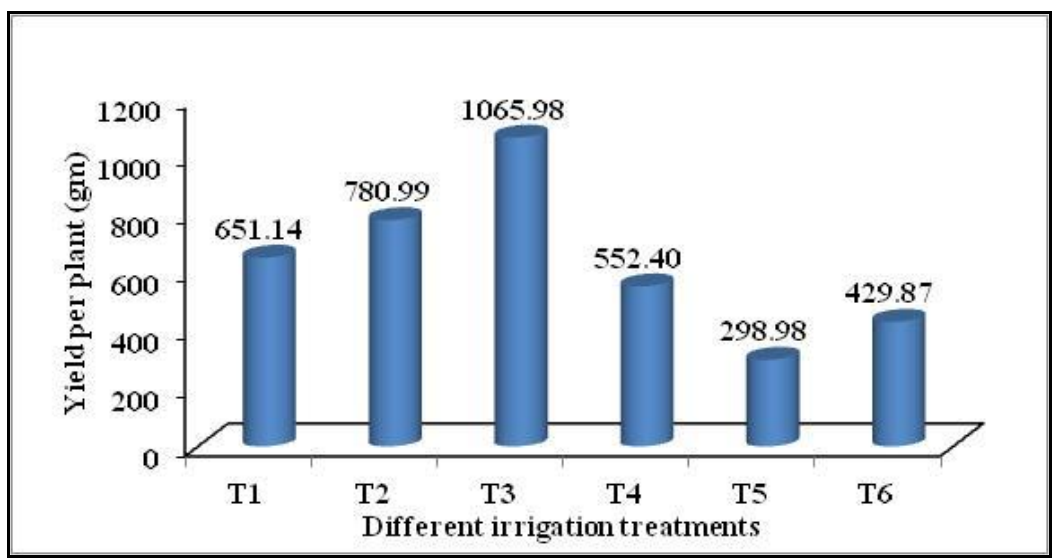

Fig.9 Effect of deficit irrigation on fruit yield per sqm area

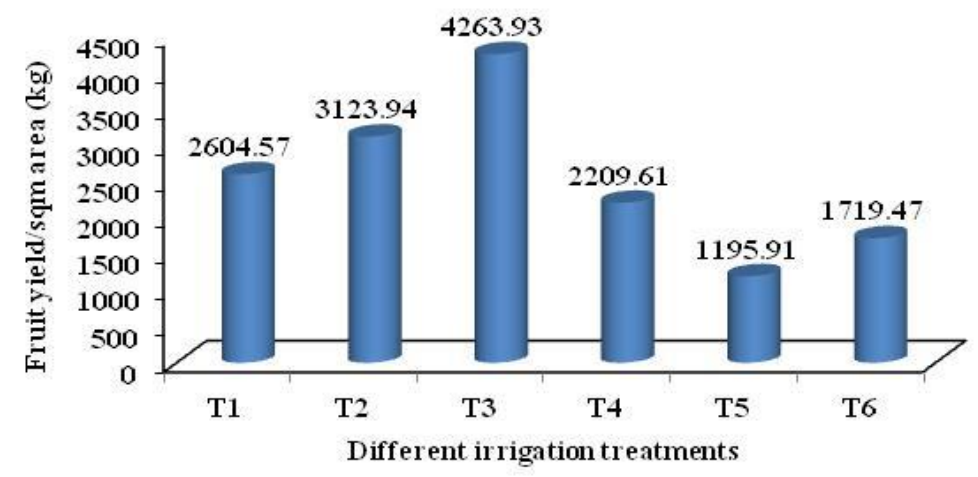


Fig.10 Effect of deficit irrigation on fruit yield

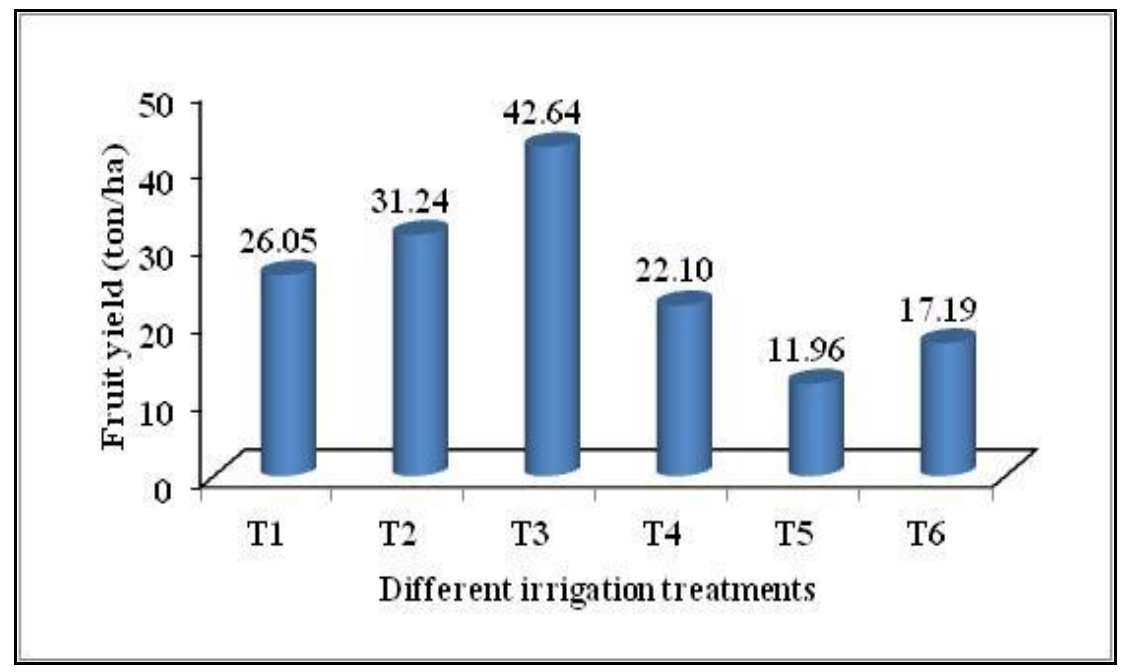

Fig.11 Effect of different treatments on water use efficiency

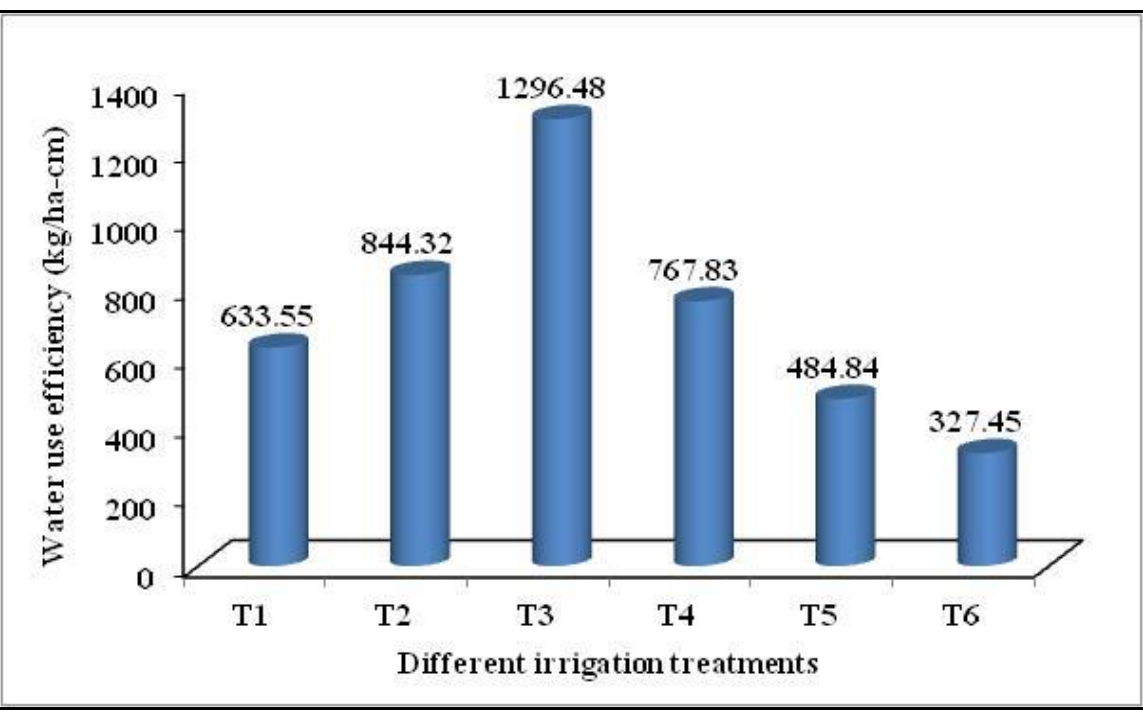

This might be due to better micro-climate responsible for efficient water utilization at early crop growth stages, which ultimately lead to more number of flowers and hence more number of fruits in $T_{3}$. On the other hand least values were recorded under $\mathrm{T}_{5}$ this might be attributed to reduced number of flowers produced rather than poor fruit set (Masuda and Hayashi, 1957). It reveals that both the excess as well as less supply of water has resulted into less number of fruits plant-1.
Hence, controlled irrigation is essential for having higher fruit number in capsicum as this crop is sensitive to both excess and under irrigations (Anonymous, 2009).

The results of this study showed that deficit irrigation practice can save up to $20 \%$ of irrigation water. Statistical analysis of the observed data showed maximum average plant height $(180 \mathrm{~cm})$, average number of leaves per plant (57.28), early flower 
initiation (26 DAT), early first harvesting of plant (60 DAT), number of flower per plant (17.78), cumulative number of fruits per plant (11.31), percent fruit set $(51.07 \%)$, individual fruit weight $(94.33 \mathrm{gm})$, fruit yield per plant (1065.98 gm/plant) and water use efficiency $(1296.48 \mathrm{~kg} / \mathrm{ha}-\mathrm{cm})$ in treatment $\mathrm{T}_{3}$ at 150 DAT (i.e., irrigation with $80 \%$ of crop evapotranspiration with mulch) under the naturally ventilated polyhouse. Among the different irrigation treatment, treatment $T_{3}$ found best and treatment $T_{5}$ least reproductive in terms of both crop growth and yield production of plant. Drip irrigation applied with $80 \%$ of crop evapotranspiration $\left(\mathrm{ET}_{\mathrm{c}}\right)$ was found to be the optimum irrigation amount in order to obtain the maximum capsicum yield of 42.64 ton/ha. Thus, the results revealed that all the vegetative parameters, reproductive parameter, quantity parameter and water use efficiency was found maximum in the drip irrigation applied with $80 \%$ of crop evapotranspiration $\left(\mathrm{ET}_{\mathrm{c}}\right)$ with mulch i.e. treatment $\left(\mathrm{T}_{3}\right)$.

\section{References}

Anonymous, 2016. ICAR-IIVR, Annual Report. ICAR-Indian Institute of Vegetable Research, Varanasi.

Arya, C.K., Purohit, R.C., Dashora, L.K., Singh, P.K. and Kothari, M. 2017. Estimation of Irrigation Water Requirement of Drip Irrigated Bell Pepper (capsicum annuum 1. var. Grossum) in Jhalawar District of Rajasthan. Chemical Science Review and Letters 6: Anonymous, 2009. Water requirement of vegetable crops. American Vegetable Grower 26, 92-95. 225-230.

Cabrera, J.R., Zotarelli, L., Dukes, M.D., Rowland, D.L. and Sargent, S.A. 2016. Soil moisture distribution under drip irrigation and seepage for potato production. Agricultural Water
Management. 169: 183-192.

Chakraborty, D., Nagarajan, S., Aggarwal, P., Gupta, V.K., Tomar, R.K., Garg, R.N., Sahoo, R.N., Sarkar, A., Chopra, U.K., Sarma, K.S.S., Kalra, N., 2008. Effect of mulching on soil and plant water status, and the growth and yield of wheat (Triticum aestivum L.) in a semiarid environment. Agric. Water Manag. 95, 1323-1334.

Dong, H.Z., Li, W.J., Tang, W., Zhang, D.M., 2009. Early plastic mulching increases stand establishment and lint yield of cotton in saline fields. Field Crops Res. 111, 269-275.

Fabrizzi, K.P., Garcia, F.O., Costa, J.L., Picone, L.I., 2005. Soil water dynamics, physical properties and corn and wheat responses to minimum and no-tillage systems in the southern Pampas of Argentina. Soil Tillage Res. 81: 57-69.

Jordan, A., Zavala, L.M., Gil, J., 2010. Effects of mulching on soil physical properties and runoff under semi-arid conditions in southern Spain. Catena 81, 77-85.

Kaushal, A., Patole, R. and Singh, K. G. 2012. Drip irrigation in sugarcane: A review, Journal of Agriculture Review 33: 211-219.

Mane, V. S. and N.K. Urmani (1981). Application of mulch at various stages of crop growth under dry land condition. Indian J. Agron., 26: 1-6.

Masuda, T., Hayashi, K., 1957. Studies on peppers. II. Effects of soil moisture on flowering, fruit setting and maturing of red pepper. Studies from Institute of Horticulture,

Neelam, P. and Rajput, T. B. S. 2010. Environment monitoring and estimation of water requirement inside a polyhouse through internet. Available at http://i rncid.org/GetFileArticles.aspx?FilePrm =7247_86680.pdf.

Olasantan, F.O., 1999. Effect of time of 
mulching on soil temperature and moisture regime and emergence, growth and yield of white yam in western Nigeria. Soil Tillage Res. 50, 215-221.

Shankara, S., Hebbar, Balakrishna, B., Prabhakar, M., Srinivas, V., Kumar N.A., Ravikumar, G.S., Ganeshan, G., Sharma, D.V., Rao, S., Doijode, S.D., Hegde, M.R. and Rao, M.S. 2011. Protected cultivation of capsicum. Technical bulletin No. 22: 1-2.

Sharma, P.K., Kharwara, P.C., Tewatia, R.K., 1990. Residual soil moisture and wheat yield in relation to mulching and tillage during preceding rainfed crop. Soil Tillage Res. 15, 279-284.

Thangam, M., Devi, S.P., Safeena, S.A., Desai, A.R., Arunachalam, V., Gupta, M.J. and Singh, N. P. 2013. Coloured Capsicum Cultivation under Naturally Ventilated Polyhouse. Extension Folder 62.

World Bank (2003). Crop and Water Productivity of the Pakistan Wheat and Rice Systems. Generaal Foulkesweg 286703 BS Wageningen, the Netherlands. www.WaterWatch.nl.

\section{How to cite this article:}

Dimple, S.R. Bhakar, S.S. Lakhawat and Kothari, M. 2017. Effect of Deficit Irrigation and Plastic Mulch on Yield and Water Use Efficiency of Drip Irrigated Capsicum under Naturally Ventilated Polyhouse. Int.J.Curr.Microbiol.App.Sci. 6(12): 2878-2889. doi: https://doi.org/10.20546/ijcmas.2017.612.335 